\title{
Perbedaan Hasil Belajar Matematika Siswa ditinjau dari Level Geometri Van Hiele SMP Kelas VII
}

\author{
Azwar Anwar \\ Pendidikan Matematika, FKIP, Universitas Borneo Tarakan, Tarakan \\ e-mail: azwaranwar99@gmail.com
}

\begin{tabular}{l} 
INFORMASI ARTIKEL \\
\hline Keywords: \\
Learning Outcomes, \\
Van Hiele's Level \\
Geometry \\
Kata Kunci: \\
Hasil Belajar, Level \\
Geometri Van Hiele \\
Cara Mengutip: \\
Anwar, A. (2019), \\
Perbedaan Hasil \\
Belajar Matematika \\
Siswa ditinjau dari \\
Level Geometri Van \\
Hiele SMP Kelas VII. \\
Mandalika \\
Mathematics and \\
Education Journal, \\
1(2), 74-80.
\end{tabular}

\begin{abstract}
This study aims to determine the distribution of student geometry levels based on Van Hiele's theory and find out the differences in students' mathematics learning outcomes in grade VII junior high school. The sampling technique is probability sampling and a sample of 182 students is obtained. Data collection techniques used were Van Hiele level geometry tests and test results. Data analysis used descriptive statistics and anova with a significance level of $5 \%$. The results showed that only 170 students were included in the Van Hiele geometry level, namely 62 students were at level 0,97 students were at level 1,5 students were at level 2 , and as many as 6 students are at level 3. In the inferential analysis based on analysis of variance (two-way anova) concludes that for learning outcomes based on Van Hiele level geometry obtained Fcount $=13.793>$ Ftable $=9.28$ means $\mathrm{H}_{0}$ is rejected means that there are differences in mathematics learning outcomes based on Van Hiele geometry level.
\end{abstract}

\begin{abstract}
ABSTRAK
Penelitian ini bertujuan untuk mengetahui distribusi level geometri siswa berdasarkan teori Van Hiele dan mengetahui perbedaan hasil belajar matematika siswa di kelas VII SMP. Menggunakan teknik probability sampling dan diperoleh sampel sebanyak 182 siswa. Teknik pengumpulan data yang digunakan adalah tes level geometri Van Hiele dan tes hasil belajar. Analisis data menggunakan statistik deskriptif dan anova dengan taraf signifikansi sebesar 5\%. Hasil analisis data menunjukkan bahwa dari 182 sampel, hanya 170 siswa yang termasuk dalam level geometri Van Hiele yaitu 62 siswa berada pada level 0 , sebanyak 97 siswa pada level 1 , sebanyak 5 siswa pada level 2, dan 6 siswa pada level 3. Analisis anova dua arah diperoleh $F_{\text {hitung }}=13,793>F_{\text {tabel }}=9,28$ berarti $\mathrm{H}_{0}$ ditolak yang artinya terdapat perbedaan hasil belajar matematika berdasarkan level geometri Van Hiele.
\end{abstract}




\section{Pendahuluan}

Pendidikan merupakan usaha sadar untuk menumbuh kembangkan potensipotensi peserta didik melalui kegiatan pengajaran. Pada zaman globalisasi seperti sekarang ini, pendidikan sangat diperlukan untuk menambah wawasan dalam ilmu pengetahuan. Melalui pendidikan diharapkan dapat mencapai perkembangan yang optimal. Oleh karena itu siswa dituntut aktif, kreatif, dan inovatif dalam merespon setiap pelajaran yang diajarkan guna meningkatkan kualitas pendidikan.

Matematika sebagai salah ilmu dasar telah berkembang pesat yang banyak digunakan dalam kehidupan sehari-hari baik materi maupun kegunannya. Dengan demikian setiap upaya pengajaran matematika sekolah haruslah selalu mempertimbangkan perkembangan matematika, penerapan dan penggunaan matematika untuk menyelesaikan permasalahan sehari-hari. Salah satu cabang matematika yang diajarkan di sekolah adalah geometri. Geometri adalah suatu cabang dari matematika yang mempelajari titik, garis, sudut, bidang serta ruang. Mempelajari geometri, siswa membutuhkan suatu konsep yang baik sehingga siswa mampu memahami geometri yang dimiliki seperti memvisualisasikan, mengetahui bangun datar dan ruang, mendeskripsikan gambar, sketsa gambar dan kemampuan untuk mengenal perbedaan dan kesamaan antar bangun geometri [1].

Prestasi geometri siswa di Indonesia tergolong rendah. Bukti-bukti empiris dilapangan juga menunjukkan bahwa masih banyak siswa yang mengalami kesulitan dalam belajar geometri, mulai tingkat dasar sampai perguruan tinggi. Dalam proses belajar mengajar matematika, khususnya pembelajaran geometri dipengaruhi faktor eksternal [2]. Pada umumnya dalam proses belajar siswa hanya menghafal rumus tanpa memahami konsep sehingga siswa kurang memahami asal rumus yang digunakan untuk menghitung luas bangun datar segi empat. Hasil observasi, menunjukkan bahwa hal tersebut timbul karena guru tidak memberi kesempatan siswa terlibat langsung dalam pembelajaran dan cara memanfaatkan alat peraga tidak maksimal dikarenakan alat peraga bangun datar segi empat tidak digunakan untuk menemukan konsep yaitu hanya menunjukkan jenis-jenis segiempat sehingga aktivitas siswa dan kreatifitas siswa masih kurang dalam proses belajar.

Berdasarkan kondisi tersebut, perlu dicari alternatif lain dalam pembelajaran geometri yang berorientasi kepada pemahaman siswa sehingga belajar menjadi aktif dan dinamis. Oleh karena itu, perlu dirancang pembelajaran matematika yang melibatkan siswa secara aktif. Salah satu ahli pendidikan yang juga memperhatikan tingkat kemampuan kognitif adalah Van Hiele. Penelitian yang dilakukan Van Hiele melahirkan beberapa kesimpulan mengenai tahap-tahap perkembangan kognitif anak dalam memahami geometriterutama dalam berpikir geometri. Guru harus mampu mendeskripsikan proses berpikir siswa dalam menyelesaikan soal/masalah, sehingga dapat menentukan tingkat berpikir geometri siswa [3].

Teori Van Hiele adalah suatu teori tentang berpikir siswa dalam mempelajari geometri, dimana siswa tidak dapat naik ke tingkat yang lebih tinggi tanpa melewati tingkat yang lebih rendah. Teori Van Hiele pertama kali dikembangkan 
oleh Pierre Marie Van Hiele dan Dina Van Hiele-Geldof dalam disertasi yang terpisah di Universitas Utrecht pada tahun 1957. Teori ini menjelaskan mengenai perkembangan berpikir siswa dalam belajar geometri. Mereka berpendapat bahwa dalam mempelajari geometri para siswa mengalami perkembangan kemampuan berpikir melalui tahap-tahap tertentu. Pengorganisasian pembelajaran dan isi materi merupakan faktor penting dalam pembelajaran, selain guru juga memegang peranan penting dalam mendorong kecepatan berpikir siswa melalui suatu tahapan. Tahap berpikir yang lebih tinggi hanya dapat dicapai melalui latihan-latihan yang tepat bukan melalui ceramah semata.

Teori Van Hiele menyatakan tingkat berpikir geometri siswa secara berurutan melalui 5 tahap/level. Van Hiele [6] menyatakan bahwa terdapat 5 tingkat berpikir anak dalam bidang geometri, yaitu :

1. Tingkat 0 (visualisasi). Pada tingkat ini siswa mengenal bentuk-bentuk geometri hanya sekedar karakteristik visual dan penampakannya.

2. Tingkat 1 (analisis). Pada tingkat ini siswa sudah mulai mengenal sifat-sifat yang dimiliki bangun geometri yang diamati.

3. Tingkat 2 (deduksi informal). Pada tingkat ini siswa mengenal dan memahami sifat-sifat suatu bangun geometri yang satu sama yang lainnya saling berhubungan.

4. Tingkat 3 (deduksi). Pada tingkat ini siswa telah mampu menarik kesimpulan secara deduktif, yaitu menarik kesimpulan yang bersifat umum dan menuju ke hal-hal yang bersifat khusus.

5. Tingkat 4 (rigor). Pada tingkat ini siswa sudah mulai menyadari pentingnya ketepatan prinsip-prinsip dasar yang melandasi suatu pembuktian.

Perkembangan berpikir Van Hiele [4] menekankan pada peran siswa dalam mengkontruksi pengetahuan secara aktif. Siswa tidak akan berhasil jika hanya belajar dengan menghafal fakta-fakta, nama-nama, aturan-aturan, melainkan siswa harus menentukan sendiri hubungan-hubungan saling keterkaitan antara konsep-konsep geometri daripada proses-proses geometri. Pembelajaran yang menekankan pada level perkembangan berfikir Van Hiele level 0 (visualisasi), level 1 (analisis), level 2 (deduksi informal), level 3 (deduksi), dan level 4 (rigor) dapat membantu perencanaan pembelajaran dan memberikan hasil yang memuaskan [5]. Oleh karena itu, tujuan dari penelitian ini adalah untuk mengetahui distribusi level geometri siswa berdasarkan teori Van Hiele dan mengetahui perbedaam hasil belajar matematika siswa berdasarkan level geometri Van Hiele di kelas VII SMP.

\section{Metode}

Jenis rancangan penelitian yang digunakan adalah penelitian kuantitatif dengan penelitian ex post facto. Penelitian ini dilakukan di SMP Negeri 10 Samarinda kelas VII dengan jumlah sampel 182 siswa.

Kriteria penskoran pada tes geometri Van Hiele yaitu (1) Setiap level ada 5 soal dan skor masing-masing soal adalah 10, (2) Siswa dapat dikatakan benar menjawab soal jika sudah mencapai skor 8 per soal, (3) Siswa dikatakan mencapai level tertentu jika mampu menjawab minimal 3 dari 5 soal dengan benar, (4) jika siswa tidak mampu mengerjakan soal pada level tertentu maka siswa tersebut 
dianggap gagal pada level berikutnya. Uji hipotesis yang digunakan adalah uji Anova untuk menguji perbedaan hasil belajar matematika ditinjau dari level geometri Van Hiele.

\section{Hasil dan Pembahasan}

Berdasarkan variabel terikat dan variabel bebas yang diteliti, dan sesuai dengan perumusan masalah peneitian, maka data dalam penelitian ini dikelompokkan menjadi tiga yaitu data level geometri Van Hiele dan hasil belajar matematika. Adapun jumlah sampel penelitian yang yaitu berjumlah 182 siswa, terdapat 12 siswa yang tidak mencapai level geometri Van Hiele. Jadi siswa yang mencapai level geometri Van Hiele adalah 170 siswa kelas VII SMP.

Penelitian ini menggunakan level 0 sampai level 3. Level 4 tidak digunakan dikarenakan terlalu tinggi dan sulit bagi siswa SMP kelas VII. Instrumen level geometri Van Hiele menggunakan soal sebanyak 20 butir berupa soal uraian. Setiap levelnya terdiri dari 5 soal. Siswa mampu mencapai level tertentu jika mampu menjawab minimal 3 soal dengan benar dari 5 soal per levelnya. Apabila seorang siswa telah gagal pada level tertentu, maka siswa tersebut dianggap gagal pada level berikutnya. Disribusi dan skor yang diperoleh dari soal uraian level geometri Van Hiele dapat dilihat pada Tabel 1.

Tabel 1. Deskripsi Level Geometri Van Hiele

\begin{tabular}{ccccc}
\hline \multirow{2}{*}{$\begin{array}{c}\text { Level Geometri Van } \\
\text { Hiele }\end{array}$} & Jumlah & $\begin{array}{c}\text { Seskripsi Statistik } \\
\text { Terendah }\end{array}$ & $\begin{array}{c}\text { Skor } \\
\text { Tertinggi }\end{array}$ & Rata-rata \\
\cline { 2 - 5 } & 62 & 46,00 & 143,00 & 96,03 \\
Level 0 & 97 & 67,00 & 148,00 & 108,56 \\
Level 1 & 5 & 121,00 & 168,00 & 139,20 \\
Level 2 & 6 & 157,00 & 181,00 & 169,00 \\
Level 3 & & & & \\
\hline
\end{tabular}

Instrumen hasil belajar matematika menggunakan soal yang berjumlah 6 butir soal uraian. Dari deskripsi data hasil belajar matematika berdasarkan level geometri Van Hiele diperoleh rata-rata skor 36,79; standar deviasi sebesar 20,575; varians 423,334; skor tertinggi dan skor terendah masing-masing 4 dan 198.

Berdasarkan hasil uji hipotesis diperoleh $\mathrm{F}_{\text {hitung }}=13,793$ dan $\mathrm{F}_{\text {tabel }}=2,60 . \mathrm{F}_{\text {hitung }}$ $>\mathrm{F}_{\text {tabel }}$ sehingga $\mathrm{H}_{0}$ ditolak. Berdasarkan hasil analisis dapat disimpulkan bahwa terdapat perbedaan hasil belajar matematika ditinjau dari level geometri Van Hiele. Deskripsi hasil belajar matematika ditinjau dari level geometri Van Hiele dapat dilihat pada Tabel 2.

Perbedaan hasil belajar matematika ditinjau dari level geometri Van Hiele menunjukkan bahwa hasil belajar matematika pada siswa setiap levelnya berbeda. Hal ini dapat dilihat dari nilai rata-rata hasil belajar matematika serta nilai maksimum dan minimum pada setiap levelnya. Semakin tinggi levelnya maka nilai rata-rata hasil belajar juga semakin tinggi. 
Tabel 2. Deskripsi Hasil Belajar Matematika Ditinjau Dari Level Geometri Van Hiele

\begin{tabular}{ccccc}
\hline \multirow{2}{*}{$\begin{array}{c}\text { Level Geometri } \\
\text { Van Hiele }\end{array}$} & Jumlah & $\begin{array}{c}\text { Deskripsi Statistik } \\
\text { Terendah }\end{array}$ & $\begin{array}{c}\text { Skor } \\
\text { Tertinggi }\end{array}$ & Rata-rata \\
\cline { 2 - 5 } & 62 & 4,00 & 79,00 & 31,10 \\
Level 0 & 97 & 6,00 & 98,00 & 37,24 \\
Level 1 & 5 & 11,00 & 98,00 & 50,22 \\
Level 2 & 6 & 67,00 & 96,00 & 77,25 \\
Level 3 & &
\end{tabular}

Berikut adalah penjelasan perbedaan hasil belajar matematika ditinjau dari level geometri Van Hiele:

1. Hasil Belajar Matematika Level 0

Pada level 0 rata-rata kemampuan siswa yaitu 31,10 termasuk dalam kategori rendah. Pada level ini hanya mengenal bentuk-bentuk geometri. Pada level ini juga hanya sekedar karakteristik visual dan penampakkannya namun rataratanya masih rendah

2. Hasil Belajar Matematika Level 1

Pada level 1 rata-rata kemampuan siswa adalah 37,24 termasuk dalam kategori rendah. Pada level ini siswa sudah mampu mengenal sifat-sifat pada bangun geometri. Siswa yang sudah mampu menemukan sifat-sifat bangun datar dapat menyelesaikan permasalahan yang melibatkan sifat bangun datar secara tertulis maupun lisan [7]. Jumlah siswa yang paling banyak ada pada level ini. Hal ini menunjukkan bahwa kemampuan rata-rata sampai pada level ini.

3. Hasil Belajar Matematika Level 2

Pada level 2 rata-rata kemampuan siswa adalah 50,24 termasuk dalam kategori sedang. Pada level ini siswa sudah mampu hubungan bangun geometri satu sama yang lainnya, misalnya siswa diberikan model bangun datar segiempat yaitu persegi panjang, persegi, jajargenjang, belah ketupat, layang-layang, dan trapesium. Siswa diminta untuk mengukur panjang sisi, besar sudut, dan panjang diagonal serta membuktikan sifat-sifat bangun datar segiempat berdasarkan bentuknya [8]

4. Hasil Belajar Matematika Level 3

Pada level 3 rata-rata kemampuan siswa adalah 77,25 termasuk dalam kategori tinggi. Pada level 3 kemampuan siswa sudah mulai menarik kesimpulan yang bersifat umum dan menuju ke hal-hal yang khusus. Kemampuan siswa pada level ini memang sangat baik karena sudah pada level yang tinggi karena siswa mampu berpikir secara logis.

Berdasarkan urutan tahap-tahap ini level geometri Van Hiele kemampuan siswa hanya mampu sampai pada level 3 , karena tidak ada satupun siswa yang mampu mencapai level 4 (pembuktian). Namun, kemampuan pada sampai level 3 ini termasuk kemampuan siswa baik walaupun masih sedikit siswa mampu mencapai level ini. Level geometri Van Hiele mempunyai tingkatan dan karakteristik geometri yang berbeda-beda. Hal ini juga mempengaruhi kemampuan siswa yang memiliki kemampuannya berbeda-beda sehingga ini menjadi perhatian yang lebih bagi guru untuk memberikan pembelajaran sesuai kemampuan berpikir siswa 
dalam merencanakan model pembelajaran yang disesuaikan dengan tingkat berpikir siswa, salah satunya model pembelajaran yang sesuai dengan tingkat berpikir van Hiele yaitu pembelajaran geometri berdasarkan Van Hiele [1]. Tahapan-tahapan pembelajaran geometri van Hiele memungkinkan siswa memiliki kepercayaan diri dalam mengkomunikasikan ide pada guru dan teman dalam kelompok, rajin dan tekun dalam mengerjakan tugas matematika, mempunyai minat dalam belajar matematika, mengaplikasikan matematika dalam kehidupan sehari-hari [9].

\section{Penutup}

Berdasarkan hasil penelitian dan pembahasan, kesimpulan yang diperoleh adalah: (1) Distribusi level geometri Van Hiele kelas VII SMP Negeri 10 Samarinda adalah 62 siswa pada level 0 (visualisasi), 97 siswa pada level 1 (analisis), 5 siswa pada level 2 (deduksi informal), 6 siswa pada level 3 (deduksi). Secara umum, pemahaman geometri siswa SMP Negeri 10 Samarinda berdasarkan level geometri Van Hiele masih berada pada tingkat 1 (analisis); (2) Terdapat perbedaan hasil belajar matematika siswa ditinjau dari level geometri Van Hiele di kelas VII SMP Negeri 10 Samarinda. Hal ini menujukkan bahwa semakin tinggi level geometri Van Hiele yang dicapai siswa maka semakin tinggi pula hasil belajar matematika yang diperoleh.

\section{Referensi}

[1]. Goenawan Roebyanto, G dan Sri Harmini, (2006) Pembelajaran Geometri yang Berorientasi Pada Teori Van Hiele dalam Upayakan Meningkatkan Pemahaman Konsep Segiempat. Jurnal Penelitian, 1.

[2]. Nur'aini Muhassanah, Imam Sujadi \& Riyadi. (2014). Analisis Keterampilan Geometri Siswa Dalam Memecahkan Masalah Geometri Berdasarkan Tingkat Berpikir Van Hiele. Jurnal Elektronik Pembelajaran Matematika 2(1) .

[3]. Lisa Aditya D. M. (2016). Level Berpikir Geometri Menurut Teori Van Hiele Berdasarkan Kemampuan Geometri dan Perbedaan Gender Siswa Kelas VII SMPN 8 Pare-Pare. Al-Khwarizmi: Jurnal Pendidikan Matematika dan Ilmu Pengetahuan ALam, 4(2).

[4]. Douglas H. Clements \& Batista, M. T. (1992). Geometry and Spatial Reasoning.Dalam D. A Grows (Ed). Handbook of Research on Mathematics Teaching and Learning. New York: Macmillan Publishing Company.

[5]. Bobango, J. C. (1993). Geometry for All Students: Phasebased Instruction. Dalam G. Cueves \& M. Driscoll (Eds). Reaching All Students with Mathematics. Reston, VA: National Council of Teacher of Mathematics.

[6]. Slameto. (2013). Belajar dan Faktor-faktor yang Mempengaruhinya. Jakarta: Rineka Cipta. 
[7]. Abdussakir. (2009). Pembelajaran Geometri Sesuai Teori Van Hiele. Madrasah, 11(1).

[8]. Miftahul Khoiri. (2014). Pemahaman Siswa Pada Konsep Segiempat Berdasarkan Teori van Hiele. Prosiding Seminar Nasional Matematika, Universitas Jember.

[9]. Tri Nopriana. (2015). Disposisi Matematis Siswa Melalui Model Pembelajaran Geometri Van Hiele. Fibonacci: Jurnal Pendidikan Matematika \& Matematika, $1(2)$. 